\title{
DEPENDENCE OF SILICON PIN DIODE ELECTRICAL CHARACTERISTICS ON PROTON FLUENCE
}

\author{
T. Čeponis, A. Balčytis, A. Dzimidavičius, E. Gaubas, J. Kusakovskij, and K. Žilinskas \\ Institute of Applied Research, Vilnius University, Saulètekio 9, LT-10223 Vilnius, Lithuania \\ E-mail: eugenijus.gaubas@ff.vu.1t
}

Received 5 February 2010; revised 4 May 2010; accepted 17 June 2010

\begin{abstract}
A comparative analysis of capacitance-voltage $(C-V)$ and current-voltage $(I-V)$ characteristics dependent on proton irradiation fluence in the range from $7 \cdot 10^{12}$ to $7 \cdot 10^{14} \mathrm{p} / \mathrm{cm}^{2}$ has been performed in float zone (FZ) silicon PIN diodes. A $\delta$-shape and triangle profiles of radiation induced defects were formed by irradiation with protons having energy in the range from 2.0 to $2.7 \mathrm{MeV}$. Temperature-dependent variations of current $(I-T)$ at fixed reverse voltage $V_{\mathrm{R}}$ enable one to extract the thermal activation parameters. These values are found to be in a quantitative agreement with trap activation parameters measured by DLTS technique. The role of point and extended defects in correlated modifications of $C-V$ and $I-V$ characteristics of the irradiated diodes is discussed.
\end{abstract}

Keywords: radiation defects, Si PIN diodes, capacitance-voltage, current-voltage characteristics

PACS: $61.72 . J i, 61.82 . F k, 72.40 .+\mathrm{w}$

\section{Introduction}

High energy proton implantation is an effective technology for a local modification of carrier lifetime in silicon power devices [1]. The radiation technology of depth-profiled density of recombination centres enables one to design both the distribution of radiation defects, by varying proton beam energy, as well as the defect density, by varying irradiation fluence [2], respectively. Together with beneficial recombination centres, deep levels acting as carrier generation traps are produced as well. Proton irradiation reduces the reverse recovery time of the PIN rectifiers, however, this procedure causes a simultaneous increase of the forward voltage drop and of the leakage current [3]. Consequently, heat treatment procedures should be performed on the postirradiated devices to reduce the concentration of detrimental traps that stretch the device switching characteristics. Then the transforms and evolution of radiation induced defects can be governed expediently by reasonable heat treatment regimes.

In this work, fluence dependent variations of capacitance-voltage $(C-V)$ and of current-voltage $(I-V)$ characteristics in FZ Si industrial PIN diodes have been examined. Modifications of these characteristics dependent on proton beam energy, on irradiation fluence, and on temperature of heat treatments have been revealed.

\section{Samples and measurement techniques}

Industrial PIN diodes fabricated on the substrates of float zone Si material and irradiated with different proton fluences have been examined. The irradiations were performed using a proton accelerator at University of Helsinki. A $\delta$-shape profile of enhanced density of the recombination centres within a diode base region of $n$-type conductivity $\mathrm{Si}$ material was formed by irradiating with $2.0 \mathrm{MeV}$ energy protons. A triangleshape depth profile of density of these defects was created by varying gradually the energy of protons in the range from 2.0 to $2.7 \mathrm{MeV}$. The density of radiation defects has been manipulated by changing the irradiation fluence in the range from $7 \cdot 10^{12}$ to $7 \cdot 10^{14} \mathrm{p} / \mathrm{cm}^{2}$. To modify the radiation induced defects and to control the consequent changes of the functional parameters of devices, the $24 \mathrm{~h}$ isochronal annealings were performed by varying temperature in the range from 20 to $420^{\circ} \mathrm{C}$ via $60-80^{\circ} \mathrm{C}$ heat treatment steps.

Measurements of current-voltage $(I-V)$ characteristics have been performed by using a commercial sub-femtoamp source-meter Keithley 6430 instrument. Capacitance-voltage $(C-V)$ characteristics have been examined by employing the small signal AC impedance measurement technique implemented by using a high precision QuadTech $7600 L R C$-meter. A computercontrolled bias voltage source for the range of $0-500 \mathrm{~V}$ 
made of a set of batteries connected in series within a shielded box has been exploited in order to arrange the noiseless and galvanically isolated measurements. The latter is required for small signal AC measurements within frequency range of $20 \mathrm{~Hz}-2 \mathrm{MHz}$ by employing a high precision LRC-meter. Temperature dependent measurements of these $I-V$ and $C-V$ characteristics have been carried out by placing a sample into a liquid nitrogen cryostat.

\section{Results and discussion}

Contact methods are one of the most reliable means to characterize the radiation induced defects, the material electrical properties, and the functional parameters of diodes after irradiation. In this work, $I-V, I-T$, and $C-V$ measurements have been carried out to determine the radiation induced changes in diode parameters and their evolution after isochronal annealings.

\subsection{Variations of leakage current}

There are two basic mechanisms responsible for current flow under reverse bias conditions. The first is associated with thermal generation of carriers within the depleted base region, referred to as generation current, and the second is associated with diffusion of carriers in the neutral region, referred to as diffusion leakage current. Total leakage current can be written as a sum of the mentioned components $[1,4]$ :

$$
\begin{aligned}
J_{\mathrm{L}} & =J_{\mathrm{DP}}+J_{\mathrm{SC}}+J_{\mathrm{DN}} \\
& =\frac{q D_{n} n_{\mathrm{i}}^{2}}{L_{n} N_{\mathrm{A}}}+\frac{q W n_{\mathrm{i}}}{\tau_{\mathrm{sc}}}+\frac{q D_{p} n_{\mathrm{i}}^{2}}{L_{p} N_{\mathrm{D}}},
\end{aligned}
$$

where $J_{\mathrm{SC}}$ is space-charge-generation leakage current, $J_{\mathrm{DP}}$ diffusion current component from $p^{+}$region, $J_{\mathrm{DN}}$ diffusion current component from $n$ or $n^{+}$region, $q$ elementary charge, $n_{\mathrm{i}}$ intrinsic carrier concentration, $\tau_{\mathrm{sc}}$ space charge generation lifetime, $D_{n, p}$ carrier diffusion coefficient in the respective $p$ or $n$ region, $L_{n, p}$ carrier diffusion length within corresponding side of the junction, $N_{\mathrm{A}, \mathrm{D}}$ is the respective concentration of acceptors or donors. $W$ is a width of depletion region, expressed as

$$
W=\sqrt{\frac{2 \varepsilon \varepsilon_{0}\left(V_{\mathrm{bi}}+V_{\mathrm{a}}\right)}{q N_{\mathrm{D}}}} .
$$

Here, $\varepsilon$ is dielectric permittivity, $\varepsilon_{0}$ vacuum dielectric constant, $V_{\text {bi }}$ built-in barrier potential, $V_{\mathrm{a}}$ applied bias voltage. Carrier generation lifetime within a spacecharge region is commonly described by using an approach of the Shockley-Read-Hall (S-R-H) recombination statistics, as [1]

$$
\tau_{\mathrm{sc}}=\tau_{p 0} \mathrm{e}^{\left(E_{\mathrm{r}}-E_{\mathrm{i}}\right) /(k T)}+\tau_{n 0} \mathrm{e}^{\left(E_{\mathrm{i}}-E_{\mathrm{r}}\right) /(k T)},
$$

with microscopic lifetimes $\tau_{n 0}=1 / C_{n} N_{\mathrm{r}}=1 / v_{\mathrm{T} n} \times$ $\sigma_{\mathrm{c} n} N_{\mathrm{r}}$ for electrons and $\tau_{p 0}=1 / C_{p} N_{\mathrm{r}}=1 / v_{\mathrm{T} p} \times$ $\sigma_{\mathrm{c} p} N_{\mathrm{r}}$ for holes, respectively. The notifications used are the same as commonly accepted. The leakage current due to space charge generation is increased with enhancement of the reverse bias until the depletion layer no longer expands due to punch-through. At full depletion, the value of leakage current is determined only by a space-charge-generation component.

The effect of proton induced defects can be easily resolved by measuring the changes in the $I-V$ characteristics, as illustrated in Fig. 1(a) for diodes irradiated by $2.0 \mathrm{MeV}$ varying fluences. An increase of leakage current is clearly observed with enhancement of fluence, and a linear leakage current increase with fluence at fixed reverse voltage $V_{\mathrm{R}}$ of $30 \mathrm{~V}$ has been obtained within the flat component of the reverse branch of the $I-V$ characteristic (Fig. 1(b)). This linear leakage current dependence on fluence can be explained by prevalence of the point carrier generation centres. The density of these centres is proportional to irradiation fluence.

A steep increase of a leakage current has been found at elevated reverse voltages, those values exceed a threshold of $>50 \mathrm{~V}$ in diodes irradiated by protons of fluence $>7 \cdot 10^{13} \mathrm{p} / \mathrm{cm}^{2}$ (Fig. 1(a), grey dotted curve). A threshold value of the reverse voltage for detection of this component of the steep leakage current increase is reduced with an enhancement of irradiation fluence (Fig. 1(a), light grey dash-dotted curve). This peculiarity might be cursorily explained as a manifestation of the Poole-Frenkel effect due to emission of carriers from the deep levels at a sufficient electric field due to reduction of a potential barrier at a local trap. Due to an increase of resistivity of the locally radiation damaged material area, a local enhancement of the strength of the electric field is very probable when a depth distribution of a voltage drop exists within very narrow (few microns) diode base region. Then the threshold reverse voltage value (for the steep leakage current increase) is reduced if the increment of resistivity is proportional to the irradiation fluence. Alternatively, the steep leakage current increase can be understood by involving the current percolation effects for a damaged range of a diode base. It is well known that large values of an interac- 


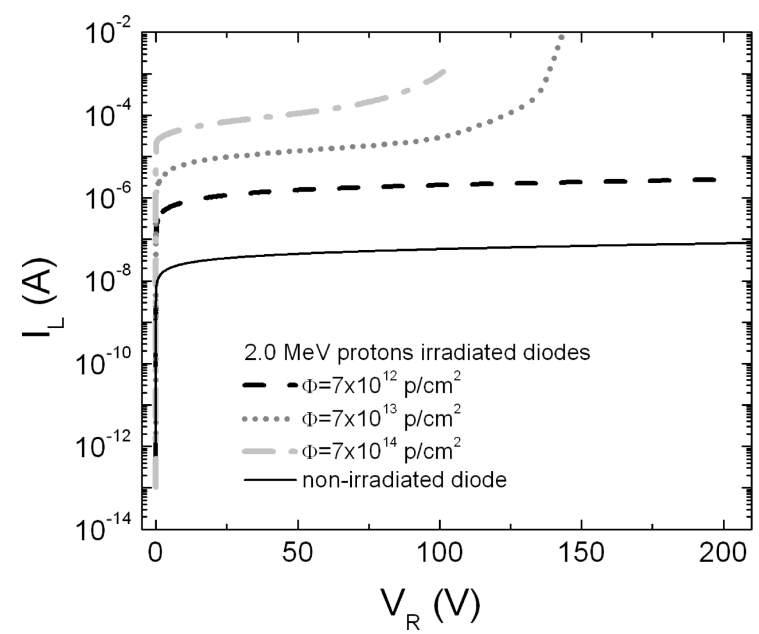

(a)

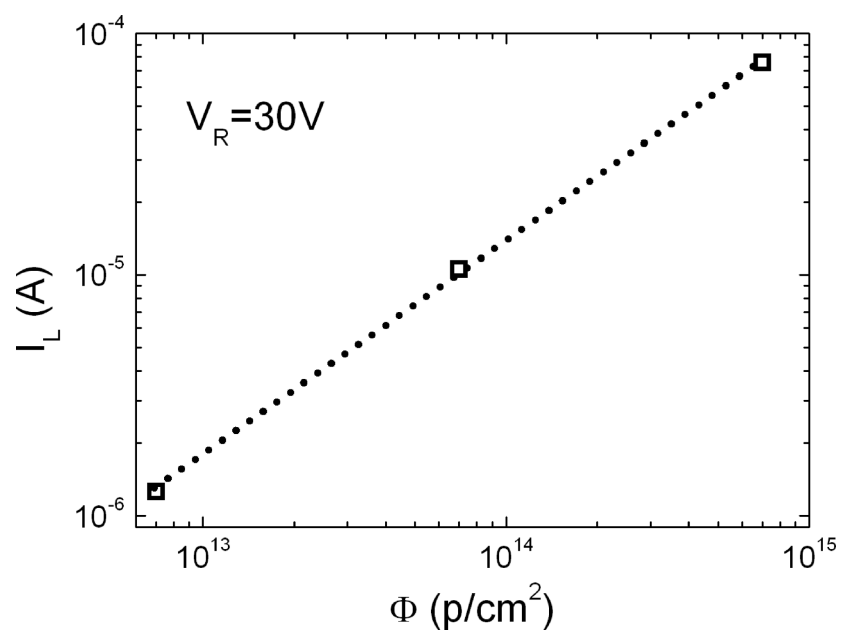

(b)

Fig. 1. (a) $I-V$ characteristics in diodes irradiated by $2.0 \mathrm{MeV}$ protons of different fluences, (b) leakage current as function of irradiation fluence at fixed bias voltage of $V_{\mathrm{R}}=30 \mathrm{~V}$.

tion cross-section in $\mathrm{Si}$ for $2-3 \mathrm{MeV}$ protons is a reason for rather short penetration depth of these particles and for creation of a high density of cluster defects within a stopping range of $2-3 \mathrm{MeV}$ protons. The existence of sharply inhomogeneous distribution of density of these cluster defects, with a rather flat pedestal within the proton penetration path and a $\delta$-shape peak density at proton stopping length, acts as extended defects with the local-field-governed space charge regions surrounding the cluster cores. Then, the applied voltage drop distributes among the space-charge areas of clusters, while the conductivity current can be ascribed to areas free of clusters, those contain only point defects. It is the latter component that determines the magnitude of a percolative current flowing along the random paths of the non-damaged material. A cross-sectional area of these channels of a relatively non-damaged material depends on density of clusters and on applied external voltage which modifies the extent of space-charge regions surrounding the clusters. The parallel and serial linkage of components of inhomogeneously damaged areas determines the total leakage current. Thus, an increase of cluster density within a pedestal component of the damage depth distribution can be a reason for reduction of a threshold voltage to observe the steep leakage current increase if applied voltage enhances an integral diameter of percolation channels.

The space charge generation current is a strong function of temperature due to the carrier thermal emission rate changes with temperature. An $I-T$ spectrum measured in a diode irradiated by $2.0 \mathrm{MeV}$ protons of fluence $\Phi=7 \cdot 10^{13} \mathrm{p} / \mathrm{cm}^{2}$ is illustrated in Fig. 2. Several peaks in current variations as a function of a reciprocal thermal energy have been resolved below a range

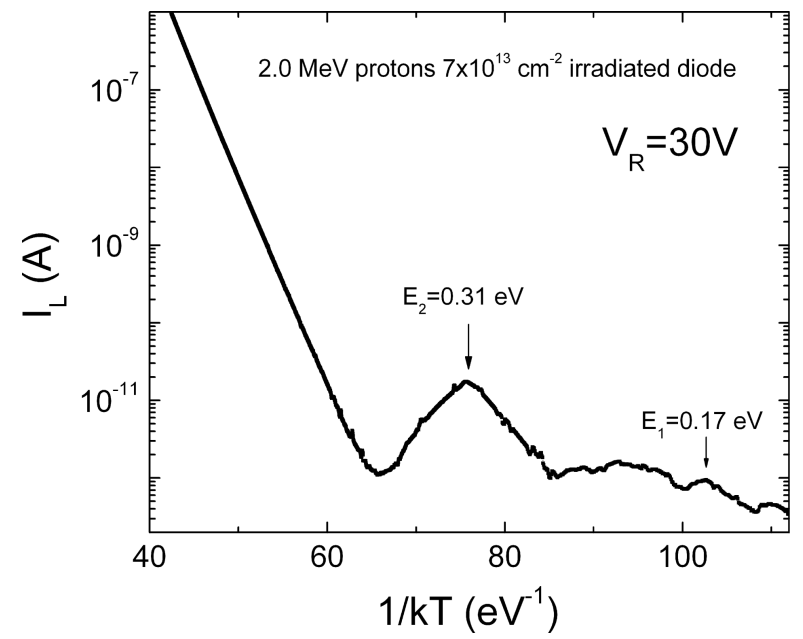

Fig. 2. $I-T$ spectrum measured in diode irradiated by $2.0 \mathrm{MeV}$ protons of fluence $\Phi=7 \cdot 10^{13} \mathrm{p} / \mathrm{cm}^{2}$. Ciphers indicate the thermal activation energy values for different deep centres resolved.

of the interband transitions stimulated by temperature changes. The activation energies of $E_{1}=0.17 \mathrm{eV}$ and $E_{2}=0.31 \mathrm{eV}$ have been deduced by a standard procedure of analysis of the slopes in symmetrical wings associated with resolved peaks in the $I-T$ dependence. The symmetrical wings can be ascribed to current variations due to dominance of thermal emission within a low temperature slope while fast capture of emitted carriers prevails in the elevated temperature wing when the same deep level associated with the fixed peak is emptied by a rather rapid emission. An impact of the rather shallow centres of activation energy values $E$ smaller than a mid-gap energy $E_{\mathrm{i}}$ can be only assumed if symmetrical slopes at peaks in the $I-T$ dependence are observed, and point-defects with discrete deep levels are associated with these peaks. 
It is commonly accepted [1] that concentration of deep centres introduced by proton irradiation is proportional to irradiation fluence $\Phi$. Then, a component $I_{\mathrm{PD}}$, associated with radiation induced change within a total leakage current due to point defects, can be estimated by introduction rate $K_{\mathrm{L}, \mathrm{PD}}$ of defect density, which is proportional to irradiation fluence but is independent of applied voltage, i. e. $I_{\mathrm{PD}}=K_{\mathrm{L}, \mathrm{PD}} \Phi$. The impact of clusters is more complicated. It is reasonable to assume that the density of clusters is also proportional to irradiation fluence but it is characterized by a different introduction coefficient $K_{\mathrm{L}, \mathrm{cl}}$. However, radiation induced clusters scale a redistribution between currents flowing due to thermal generation from point defects and the percolation (conductivity) current when cross-section of channels is governed both by density of clusters and by applied voltage. The latter determines the depletion width of space charge region surrounding the cluster. Then, a component associated with creation of clusters can be phenomenologically described by a dimensionless redistribution factor $R$, dependent on both the applied voltage and fluence, i. e. $R\left(V_{\mathrm{a}}, \Phi\right)$. Therefore, the changes of the total leakage current in proton irradiation damaged material can be qualitatively explained by using a phenomenological expression:

$$
I_{\mathrm{L}}=I_{\mathrm{i}}+K_{\mathrm{L}} \Phi+K_{\mathrm{L}, \mathrm{cl}} R\left(V_{\mathrm{a}}, \Phi\right) \Phi,
$$

where $I_{\mathrm{i}}$ is the initial leakage current of not irradiated material. Consequently, the total leakage current as a function of fluence contains the linear and nonlinear components. Threshold effects should be included within $R$ due to percolation character of current. Then, a distance between the space-charge spheres, surrounding the clusters, reduces with enhancement of fluence at assumption that density of clusters is proportional to fluence. Due to depletion/space-charge screening effects, the exponential behaviour of $R$ as a function of applied voltage $\left(V_{\mathrm{a}}\right)$ is implied for $V_{\mathrm{a}}$ values above percolation threshold. Thus, the increase of leakage current with fluence in the range below a threshold reverse voltage can be explained by a generation current from point deep centres while the introduction of clusters determines an existence of a threshold voltage and of an exponential increase segment of leakage current above threshold voltage dependent on irradiation fluence. Particular function of $\Phi$ and of $V_{\mathrm{a}}$ in description of leakage current nonlinearities can be obtained only on the basis of a cluster model, which is beyond the scope of this consideration.

\subsection{Capacitance-voltage characteristics}

Barrier capacitance of the reverse biased diode is commonly approximated by a plane capacitor approach and expressed as

$$
C=\frac{\varepsilon \varepsilon_{0} A}{d_{\mathrm{eff}}} .
$$

Here $A$ is an active area of the junction, and an effective width of depleted diode with abrupt junction is either

$$
d_{\mathrm{eff}}=\left\{\begin{array}{l}
\left.d\right|_{V_{\mathrm{R}} \geq V_{\mathrm{FD}}} \\
\left.W\right|_{V_{\mathrm{R}}<V_{\mathrm{FD}}}
\end{array},\right.
$$

equal to a geometrical length $d$ of a diode base above full depletion voltage $\left(\geq V_{\mathrm{ED}}\right)$ or it is equal to a depletion depth $W$. The latter $W$ is evaluated by solving a Poisson equation with standard boundary conditions, and it is described by Eq. (2) for abrupt junction. For homogeneously irradiated base material, the radiation induced acceptors are able to compensate the initial doping by donors of the $n$-base material or even to change the conductivity type. Therefore, the value of concentration of donors $N_{\mathrm{D}}$ in Eq. (2) should be replaced by an effective density $N_{\text {eff }}=N_{\mathrm{D}}-N_{\mathrm{A}}$ of the electrically active centres in description of the depletion width of a reversely biased irradiated diode. For sharply inhomogeneous depth $(x)$ profile of radiation defects $N_{\text {eff }}(x)$ introduced by stopped protons, the depletion depth as a function of reverse voltage is found by a digital solution of the Poisson equation. An analytical approximation of such an inhomogeneously irradiated base can be obtained by integrating a step-like profile, ascribed to a pedestal (of thickness $d_{1}$ ), to a high density of $N_{\text {eff }}$ but narrow (of thickness $d_{2}<d_{1} \ll d$ ) step in the protons' stopping range, and to a non-irradiated material of an initial doping $N_{\mathrm{D}}$, respectively. Subsequently, a cumbersome function of $W=W\left(V_{\mathrm{a}}, d_{1}, d_{2}, d\right)$ is obtained, which determines a significant deviation from the wellknown linear slopes $[3,4]$ within either $1 / C^{2}$ or $1 / C^{3}$ plots versus $V_{\mathrm{R}}$ for either an abrupt or a linear junction models, respectively.

Comparison of the measured capacitance-voltage characteristics for diode irradiated by $2.0 \mathrm{MeV}$ protons of fluence $7 \cdot 10^{12} \mathrm{p} / \mathrm{cm}^{2}$ and for non-irradiated one is presented in Fig. 3. The decrease of a slope observed at low voltages within a $C^{-2}-V_{\mathrm{R}}$ plot can be cursorily interpreted as the increase of $N_{\text {eff }}$ value from $N_{\text {eff, } n}=1.77 \cdot 10^{14} \mathrm{~cm}^{-3}$ for the non-irradiated diode to $N_{\mathrm{eff}, i}=5.47 \cdot 10^{14} \mathrm{~cm}^{-3}$ after irradiation. At higher voltages, the slope of a segment for the $C-V$ curve measured on irradiated diode coincides with that 


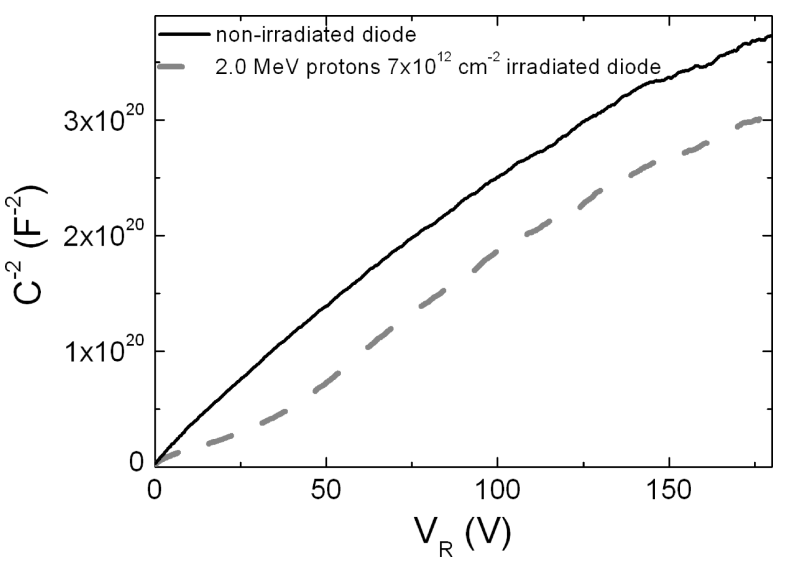

Fig. 3. $C-V$ characteristics measured on reverse biased diodes: solid black curve for non-irradiated material and dashed grey curve for diode irradiated by $2.0 \mathrm{MeV}$ protons of fluence $\Phi=$ $7 \cdot 10^{12} \mathrm{p} / \mathrm{cm}^{2}$.

for a non-irradiated one, as predicted by the simulated $W=W\left(V_{\mathrm{a}}, d_{1}, d_{2}, d\right)$ changes in the step-like $N_{\text {eff }, i-n}$ profile structure. On the other hand, the increase of a diode capacitance (i. e. a reduced value of $C^{-2}$ for irradiated diode relatively to initial one, Fig. 3) when the external field covers only a damaged layer can also be understood as a shrinkage of the depletion width due to compensation of a local space-charge field within a cluster by an external one. This proves that the $C-V$ measurement is a proper technique to control radiation induced $N_{\text {eff }}$ profile within $n$-base region.

\subsection{Modifications of diode characteristics by irradiation profile and fluence}

Current-voltage characteristics measured on diodes containing different defect distribution $N_{\text {eff }}(x)$ profiles

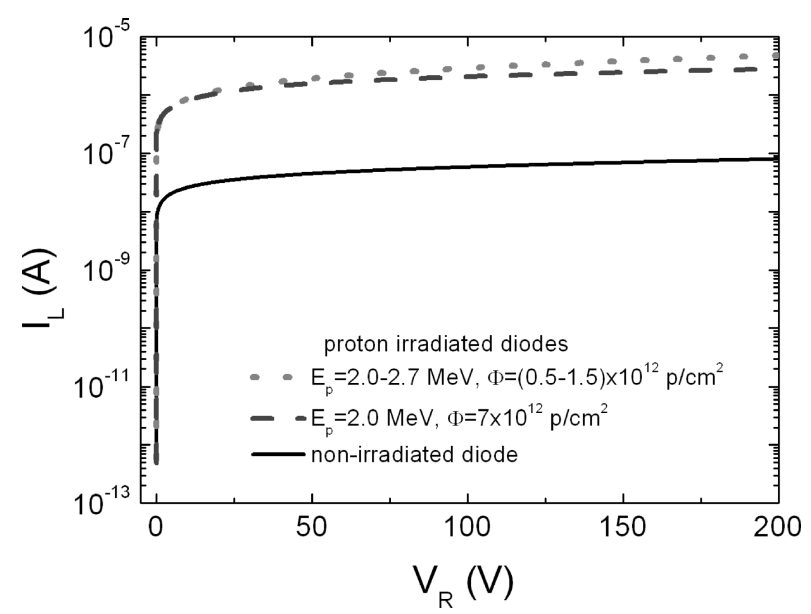

(a) formed by proton beam either of fixed $(2.0 \mathrm{MeV})$ energy or of multi-step gradually varied energy in the range of 2.7-2.0 MeV are compared in Fig. 4 for (a) reverse and (b) forward biasing branches of the $I-V$ dependences, respectively. Here, $I-V$ characteristics obtained for the smallest irradiation fluences employed in this work are presented. Also, these fluences are of nearly the same peak value for $\delta$ - and triangle-shape $N_{\text {eff }}(x)$ profiles.

The increase for both leakage (Fig. 4(a)) and forward (Fig. 4(b)) current is obtained in the irradiated diodes when comparing with those for non-irradiated material diode. A rather smooth variation of the $I-V$ curves in the typical $I-V$ saturation regions indicates dominance of the point centres. The impact of the same deep levels can be implied, when their action as generation/trapping centres is inherent. These generation centres increase the leakage current. An enhancement of the forward current with irradiation can be explained by the reduction of carrier recombination lifetime. Dominance of the point deep centres in the range of moderate reverse voltages can be corroborated by temperature dependent leakage current characteristics. These characteristics measured at $V_{\mathrm{a}} \leq 30 \mathrm{~V}$ (Fig. 5) show a significant amplitude of the $E_{1}=0.17 \mathrm{eV}$ and $E_{2}=0.31 \mathrm{eV}$ peaks (Fig. 2). Those are well-known in TSC [5] and DLTS [6] spectra and are interpreted as the vacancyoxygen and vacancy-oxygen-hydrogen point-like complexes in $\mathrm{Si}$. The amplitude of the leakage current peaks increases with enhancement of density of these radiation defects which is increased both by the irradiation fluence and by the narrowing of a damaged layer width (in the case of a $\delta$-shape profile, Fig. 5). The generation centres also determine an observable increase of

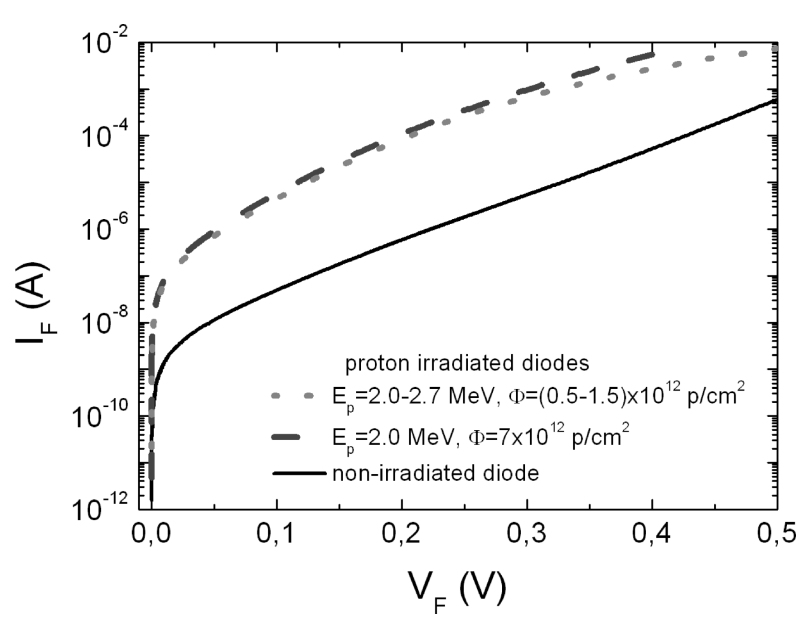

(b)

Fig. 4. $I-V$ characteristics for (a) reverse and (b) forward biased diodes. The $I-V$ of diodes with non-irradiated base (black solid curves), of diodes containing a triangle-shape proton irradiation induced $N_{\text {eff }}(x)$ (grey dotted curves) over width of diode base, and of $\delta$-shape $N_{\text {eff }}(x)$ (dark grey dashed curves) damaged layer located at $7 \mu \mathrm{m}$ from the metallurgical junction are compared. 


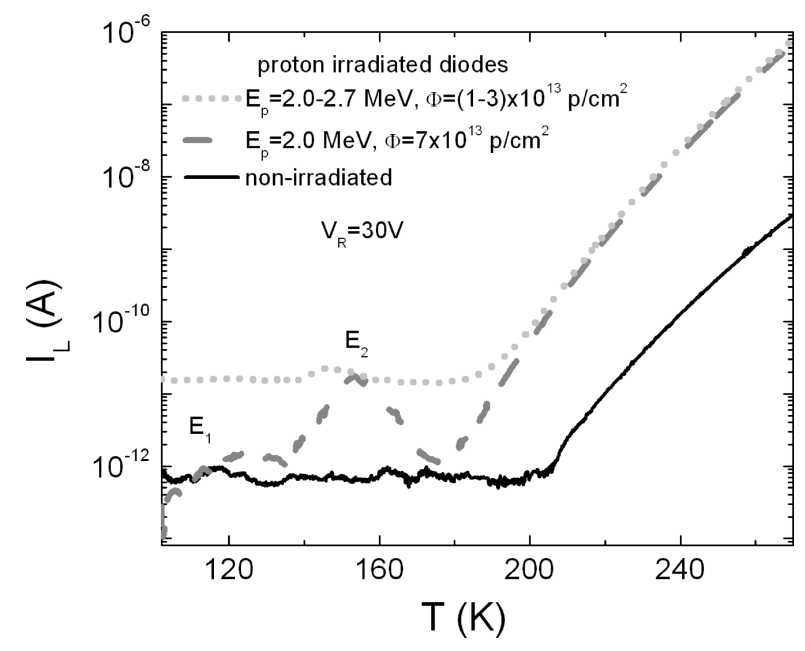

Fig. 5. Leakage current as a function of temperature measured in diodes of non-irradiated (black solid curve) material compared with those obtained for proton irradiated diodes containing a triangleshape proton irradiation induced $N_{\text {eff }}(x)$ (light grey dotted curve) over width of diode base and of a $\delta$-shape $N_{\text {eff }}(x)$ (grey dashed curve) damaged layer located at $7 \mu \mathrm{m}$ from the metallurgical junction.

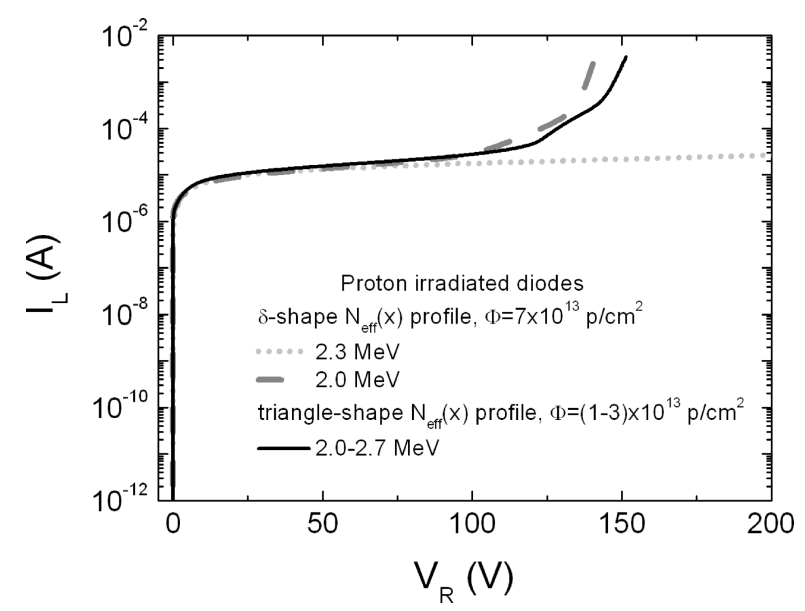

Fig. 6. $I-V$ characteristics in reverse biased diodes irradiated by 2.0 MeV (black solid curve) and by $2.3 \mathrm{MeV}$ (light grey dotted curve) protons when a $\delta$-shape damage layer is located at $7 \mu \mathrm{m}$ from metallurgical $p-n$ junction (black solid curve) and in the middle of $n$-base region (light grey dotted curve). The $I-V$ characteristic for diode containing a triangle $N_{\text {eff }}(x)$ profile (grey dashed curve), with peak located at junction, is also presented for comparison. Values of peak irradiation fluence are of close magnitude for different shape and location of the radiation damaged layers.

the averaged value of leakage current exceeding that in the non-irradiated diode (as compared in Fig. 5).

However, the discussed segment of the steep increase of a leakage current inevitably appears for the elevated reverse voltages in the proton irradiated diodes. The threshold reverse voltage value, for which the steep increase of a leakage current is detectable, depends on irradiation fluence, on defect distribution profile $N_{\text {eff }}(x)$,

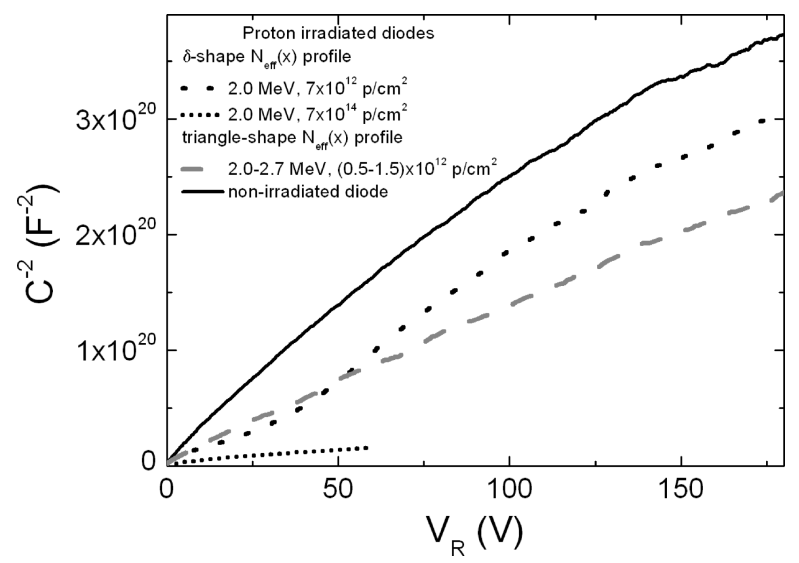

Fig. 7. $C-V$ characteristics dependent on fluence in diode with irradiation damaged $\delta$-shape layer (dotted curves) compared with those in non-irradiated diode (solid curve) and in irradiated diode containing a triangle $N_{\text {eff }}(x)$ profile (gray dashed curve).

and on location of a damaged layer relatively to a metallurgical junction, as illustrated in Fig. 6. The segment of the steep increase of a leakage current starts at a threshold reverse voltage value which is the smaller the larger irradiation fluence (Fig. 1(a)) or a closer location of the damaged layer relatively to junction (Fig. 6) is. A reduction of the threshold reverse voltage with a closer location of a peak of the damaged layer to metallurgical junction implies that the impact of the extended radiation defects, containing space-charge surroundings, exceeds that of the generation centres in the increase of leakage current dependently on the local strength of electric field. The latter is weaker in the middle of a diode base relatively to that at junction. Therefore, for the same $N_{\text {eff }}(x)$ shape layers formed by 2.0 and 2.3 MeV protons, the observed threshold reverse voltages differ significantly, when comparing the respective $I-V$ s in Fig. 6 for a layer located at junction and for a layer within the half-width of a diode base. With enhancing the cluster density when the latter is proportional to irradiation fluence, the cluster-surrounding space-charge spheres tend to overlap. Consequently, an external applied field governs the percolation current or the local field. Direction of local fields is dependent on the polarity of space charge and is caused by the cluster core structure in the space-charge it surrounds. Then, a leakage current increase is typical either to that of a forward biased junction or to avalanche processes evolved within a local strong field.

Capacitance-voltage characteristics in the as-irradiated diodes containing a $\delta$-shape and a triangle-profile layer of radiation induced defects are compared in Fig. 7 with that for non-irradiated one. A reduction of value of $C^{-2}$ with enhancement of irradiation fluence in diodes 
containing a $\delta$-shape $N_{\text {eff }}(x)$ layer located close to junction can be cursorily explained by the increase of effective doping $N_{\text {eff }}$ in the $n$-base region due to introduction of point radiation defects of donor type with densities exceeding the initial doping. But, peaks in the $I-T$ characteristics are identified as the acceptorlike point centres. On the other hand, introduction rate of point defects by irradiation of fluence $<10^{13} \mathrm{p} / \mathrm{cm}^{2}$ should be assumed to be unprecedently large for $\mathrm{Si}$. For the diodes irradiated by $2.0 \mathrm{MeV}$ protons with fluences less than $10^{13} \mathrm{p} / \mathrm{cm}^{2}$, a $C-V$ characteristic, measured at voltages of values above those necessary to cover a $\delta$-shape $N_{\text {eff }}(x)$ layer, shows a $C^{-2}-V_{\mathrm{R}}$ course parallel to that of a non-irradiated diode (Fig. 7). This implies that enhanced values of capacitance can be caused by a junction-located internal space-charge field which screens the external strong field. Subsequently, the $C^{-2}-V_{\mathrm{R}}$ course is similar to that for non-irradiated diode but with a reduced effective voltage $V_{\mathrm{R}}^{*}=V_{\mathrm{a}}-$ $V\left(E_{\text {local }}\right)$.

The increase of capacitance with irradiation fluence for the diode containing a $\delta$-shape layer located at the same distance from junction can be explained by an enhanced screening of the strong external field by increased density of clusters. The smoother profile of $N_{\text {eff }}(x)$ within a triangle shape layer (in a diode irradiated with a close value of fluence) determines the smaller density of clusters within area of the strong external field. Therefore, the capacitance for a diode containing a triangle shape layer is reduced relatively to that obtained in a diode containing a $\delta$-shape layer in the range of small reverse voltages. Existence of clusters within entire base width for a diode containing a

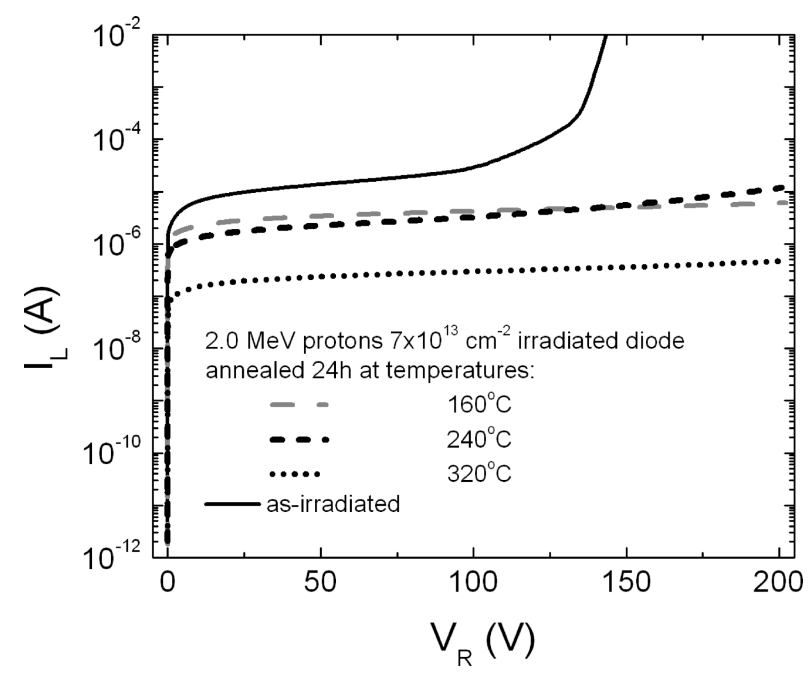

(a) triangle shape irradiation profile determines a clear deviation of the $C^{-2}-V_{\mathrm{R}}$ course from those observed for both non-irradiated and irradiated by $2.0 \mathrm{MeV}$ protons of fluence $<10^{13} \mathrm{~cm}^{-2}$ diodes, in the range of elevated $V_{\mathrm{R}} \mathrm{s}$.

Thus, coordinated variations of the $I-V, I-T$, and $C-V$ characteristics with irradiation fluence and varying $N_{\text {eff }}(x)$ profile imply that the influence of point radiation defects can be detected within current variations for the range of low bias voltages. An impact of extended cluster defects determines the non-linear current changes (might be as generation of microplasma) at elevated reverse voltages, and it appears in the $C-V$ s dependent on irradiation fluence.

\subsection{Heat treatment induced modifications of the irradiated diode characteristics}

Isochronal $24 \mathrm{~h}$ annealings by varying temperature in the range of $20-420^{\circ} \mathrm{C}$ were performed on proton irradiated diodes in order to resolve behaviour of different radiation defects under heat treatments and to determine a range of requested modifications in functional parameters of the irradiated devices.

Evolution of $I-V$ and $I-T$ characteristics for diodes irradiated by $2.0 \mathrm{MeV}$ protons of fluence $7 \cdot 10^{13} \mathrm{p} / \mathrm{cm}^{2}$ (Fig. 8(a)) and $7 \cdot 10^{14} \mathrm{p} / \mathrm{cm}^{2}$ (Fig. 8(b)) after several temperature steps within isochronous $24 \mathrm{~h}$ heat treatment is illustrated in Fig. 8. The leakage current is reduced in all the applied reverse voltage range relatively to the current values obtained in the as-irradiated diode. The steep current increase due to percolation and to avalanche current effects disappears in the whole range

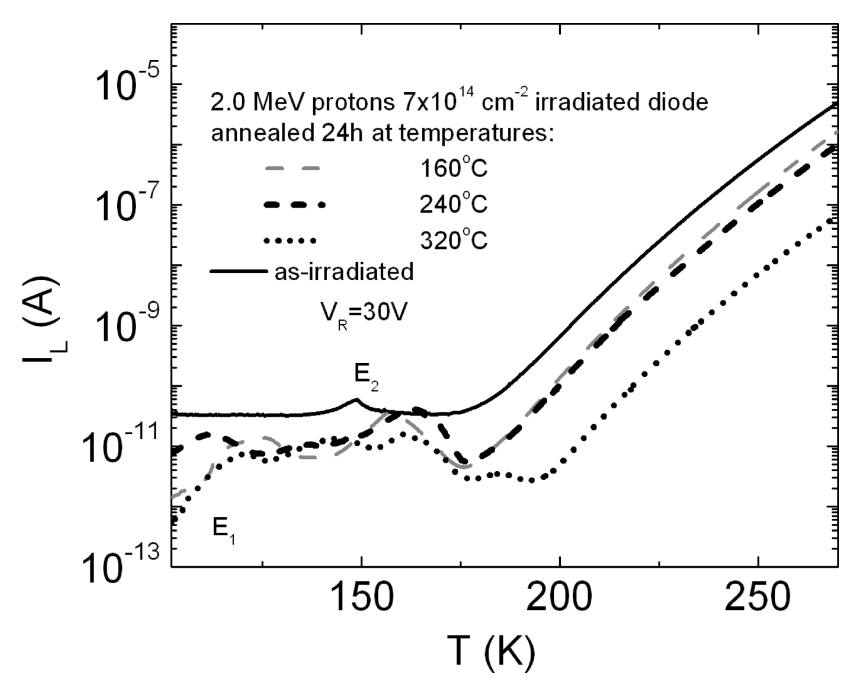

(b)

Fig. 8. Variations of the (a) $I-V$ and (b) $I-T$ characteristics in $2.0 \mathrm{MeV}$ proton irradiated diodes after various temperature steps of the isochronal $24 \mathrm{~h}$ heat treatment. 


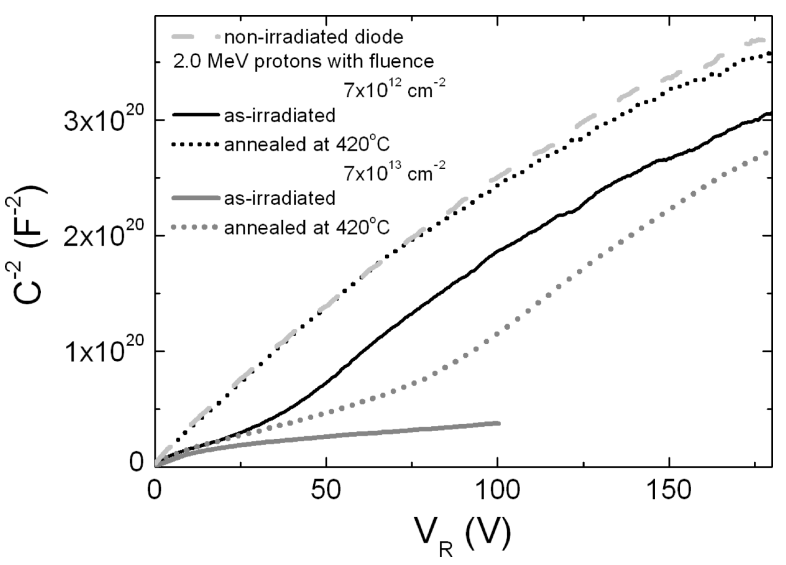

Fig. 9. Variation of the $C^{-2}-V_{\mathrm{R}}$ characteristics in the non-irradiated (light grey dashed curve) diode as well as in the as-irradiated diodes (solid curves) and in a heat treated at $420^{\circ} \mathrm{C}$ (dotted curves) diode. Capacitance changes dependent on fluence of $7 \cdot 10^{12} \mathrm{p} / \mathrm{cm}^{2}$ (black curves) and of $7 \cdot 10^{13} \mathrm{p} / \mathrm{cm}^{2}$ (grey curves) of $2.0 \mathrm{MeV}$ protons are compared.

of applied bias voltages. However, an enhancement of the heat treatment temperature above $160^{\circ} \mathrm{C}$ leads to an increase of leakage current at elevated reverse voltages. This implies a shift of the steep current increase segment towards the range of higher voltages, exceeding those employed in this investigation. The course of leakage current variation with $V_{\mathrm{R}}$ in the diode heated at $320^{\circ} \mathrm{C}$ remains similar to that obtained after annealing at $240{ }^{\circ} \mathrm{C}$. Therefore, a beneficial annealing of radiation defects can be implemented in the temperature range of $20-200^{\circ} \mathrm{C}$. This result is corroborated by $I-T$ characteristics measured in the same diodes. The initial heat temperature steps below $200{ }^{\circ} \mathrm{C}$ lead to a reduction of a leakage current value and of the amplitude of the current peaks (in the range of $<200 \mathrm{~K}$ ) relatively to those measured in the as-irradiated diode. Further enhancement of the annealing temperature causes shifts of the peaks when amplitude of the latter increases and might be of the same magnitude as measured at previous steps and even within the as-irradiated diode. These changes of the $I-T$ spectra imply transforms of the defects. However, the integral impact of the deepest centres is reduced with enhancement of heat treatment temperature up to $420^{\circ} \mathrm{C}$, and this assumption can be deduced from a decrease of the leakage current ascribed to the interband transitions (in the range of $>200 \mathrm{~K}$ ).

Variations of the $C^{-2}-V_{\mathrm{R}}$ characteristics in the asirradiated diodes (solid curves) and in heat treated at $420^{\circ} \mathrm{C}$ (dotted curves) samples are illustrated in Fig. 9 and compared with those measured in the nonirradiated diode. A $C-V$ characteristic is almost restored to that obtained in the non-irradiated diode after multi-step $24 \mathrm{~h}$ isochronous annealings of the diode irradiated by the smallest $7 \cdot 10^{12} \mathrm{p} / \mathrm{cm}^{2}$ fluence of 2.0 MeV protons, employed in this investigation. As mentioned above, the course of the $C^{-2}-V_{\mathrm{R}}$ characteristic in the as-irradiated with smallest fluence diode (for $V_{\mathrm{R}} \mathrm{S}$ above those required to deplete the width of an irradiated layer) is isomorphous to the $C^{-2}-V_{\mathrm{R}}$ characteristic measured in the non-irradiated diode. Capacitance of an as-irradiated diode increases relatively to that in the initial diode only for $V_{\mathrm{R}} \mathrm{S}$ responsible for depletion of radiation damaged layer of diode base. The heat treatment induced shrinkage of the space-charge region width (where the external electric field is screened) can be deduced by analysing a character of $C^{-2}-V_{\mathrm{R}}$ restoration in the annealed diode, irradiated by the smallest fluence of $2.0 \mathrm{MeV}$ protons. The same effect of an effective shrinkage of the space-charge region width can be observed in the $C^{-2}-V_{\mathrm{R}}$ changes in the annealed diodes irradiated by the larger fluence (Fig. 9). However, a complete restoration of the $C^{-2}-V_{\mathrm{R}}$ characteristic to that of non-irradiated diode is not reached in the latter case of large fluence. Consequently, annealing of point defects within material surrounding the cluster space-charge spheres is mostly probable and observable when the density of clusters is rather small. At elevated fluences, generation of cluster densities sufficient to change the strength of external field in vicinity of junction does not allow to suppress radiation defects by annealings.

\section{Conclusions}

Concerted analysis of changes of the $I-V$ and $C-V$ characteristics in PIN diodes with radiation damaged layers of various profiles unveiled a different impact of point and of cluster type radiation defects on transforms of diode electrical characteristics. Point-like radiationinduced and vacancy-ascribed complexes are responsible for the increase of leakage current in the range of small reverse voltages. Extended clusters, owing to a space-charge sphere surrounding a cluster with inherent charging of cluster core, modify the $C-V$ and $I-V$ characteristics when radiation damaged layers are located nearby the metallurgic junction. The $C-V$ varies due to local changes of applied external field. A steep leakage current increase in $I-V$ characteristic appears to be caused by forward biased space-charge regions around clusters or generation of microplasma in local strong fields. The local field effects, caused by the extended radiation defects, depend on cluster density gradients, and these effects are more pronounced in diodes containing a narrow $\delta$-shape radiation damaged 
layer within the diode base. Annealing of point defects within a material that surrounds the cluster spacecharge spheres is mostly probable and observable after heat treatments in the temperature range of $20-320^{\circ} \mathrm{C}$, when the density of clusters is rather small. Effects caused by elevated densities of cluster type radiation defects are hardly manageable by annealing.

\section{References}

[1] B.J. Baliga, Power Semiconductor Devices (PWS Publishing Company, Boston, 1996).

[2] P. Hazdra, J. Vobecky, and K. Brand, Optimum lifetime structuring in silicon power diodes by means of various irradiation techniques. Nucl. Instrum. Methods B 186, 414-418 (2002).

[3] D.K. Schroder, Semiconductor Material and Device Characterization (John Wiley \& Sons, New Jersey, 2006).

[4] S.M. Sze and Kwok K. Ng, Physics of Semiconductor Devices (John Wiley \& Sons, New Jersey, 2007).

[5] I. Pintilie, C. Tivarus, L. Pintilie, M. Moll, E. Fretwurst, and G. Lindstroem, Thermally stimulated current method applied to highly irradiated silicon diodes, Nucl. Instrum. Methods A 476, 652-657 (2002).

[6] P. Leveque, A. Hallen, P. Pellegrino, B.G. Svensson, and V. Privitera, Dose-rate influence on the defect production in $\mathrm{MeV}$ proton-implanted float-zone and epitaxial $n$-type silicon, Nucl. Instrum. Methods B 186, 375-379 (2002).

\title{
SILICIO PIN DIODŲ ELEKTRINIŲ CHARAKTERISTIKŲ PRIKLAUSOMYBE் NUO PROTONŲ ITÉKIO
}

\author{
T. Čeponis, A. Balčytis, A. Dzimidavičius, E. Gaubas, J. Kusakovskij, K. Žilinskas \\ Vilniaus universiteto Taikomuju mokslu institutas, Vilnius, Lietuva
}

\begin{abstract}
Santrauka
Radiacinès technologijos yra vienos efektyviausių valdant galios puslaidininkiniu prietaisu greitaveiką, formuojant ir lokalizuojant padidintos rekombinacijos sluoksnius darinio aktyviosiose srityse. Kartu su pageidautinais rekombinaciniais centrais, mažinančiais diodų atgalinès srovès atsistatymo trukmę, formuojasi ir generaciniai centrai, didinantys nuotékio sroves ir tiesioginès itampos kritimą. Šiame darbe galios PIN diodai buvo švitinami fiksuotos energijos protonais sudarant $\delta$ formos padidintos rekombinacijos sluoksni arba formuojant trikampio formos suardymo profili $n$ bazès srityje. Pastaruoju atveju laipsniškai ir suderintai buvo keičiama protonų energija ir apšvitos įtėkis. Defektų koncentracija buvo keičiama, varijuojant apšvitos įtèkị. Nepageidautiniems defektams valdyti buvo vykdomi izochroniniai $24 \mathrm{~h}$ iškaitinimai, keičiant temperatūrą $80-420^{\circ} \mathrm{C}$ intervale. Pasitelkiant sąlytinius voltamperinių $(I-V)$ ir voltfaradinių $(C-V)$ būdingụjų dydžių mata-
\end{abstract}

vimo metodus, buvo ištirti îvairių energijų protonais švitintų PIN diodų parametrų kitimai.

Analizuojant diodų, kuriuose suformuoti skirtingo defektų tankio pasiskirstymo profiliai, $I-V$ ir $C-V$ charakteristikas, pastebètas skirtingas taškinių ir klasterių tipo defektu pasireiškimas diodų elektriniu parametrų kitimuose. Taškiniai defektai ir vakansijoms priskiriami kompleksai lemia nuotèkio srovès padidejjimą mažu atgalinių įtampų srityje. Tuo tarpu klasteriai dèl juos supančios erdvinio krūvio sferos modifikuoja $C-V$ charakteristiką (dèl lokalaus elektrinio lauko) ir nulemia staigu nuotèkio srovès išaugimą, kai suardymo spinduliuote sluoksniai yra netoli metalurginès sandūros. Lokalaus lauko efektai priklauso nuo klasteriu tankio ir labiau pasireiškia dioduose, kuriuose suformuotas $\delta$ pavidalo padidintos rekombinacijos spartos profilis $n$ bazès srityje. Atskleista, kad taškiniai defektai išsikaitina $20-320^{\circ} \mathrm{C}$ temperatūrų intervale, tuo tarpu klasterių tipo defektai išsilaiko po diodų iškaitinimų. 